\title{
Bearing capacity of piles in a reinforced by pressure cementation soil massif
}

\author{
Ildus Shakirov ${ }^{1 *[0000-0003-4899-449 X]}$ \\ ${ }^{1}$ Kazan State University of Architecture and Engineering, Kazan, Tatarstan Republic, Russia, \\ Zelenaya street, 1
}

\begin{abstract}
Studies of the piles bearing capacity after strengthening soil by cement mortar pressure injection were carried out to determine pile foundations bearing capacity increasing patterns in a result of soils cementation. Depending from the volume and cement mortar technological injection parameters, the soil stress state around the pile changes, additional pile-soil compression occurs and the friction along the lateral surface increase, as well as the soil resistance under the pile bottom end. Cementation effect on the pile bearing capacity for different injectors location and the number of piles in the foundation were determined by tests. The research results can be used in the pile foundations reinforcement design in conditions of reconstruction with increasing loads on the foundations.
\end{abstract}

Keywords: ground base, soil massif, strengthening, cementation, pile foundation, bored pile, bearing capacity.

\section{Introduction}

In the process of performing reconstruction work on the buildings and structures, with increasing loads, it is often necessary to increase the pile foundations bearing capacity. Reinforcement of the pile foundation may also be required if the soil characteristics surrounding the pile deteriorate, for example, due to increased humidity. To increase the pile foundation bearing capacity, you can apply the method of laying additional piles. Currently, to strengthen foundations, are widely used various types of piles, carried out according to various technologies [1, 2]. However, the installation of additional piles is associated with a high cost and the necessary to design structures that transfer the load from the existing foundation to the new piles, which complicates the implementation of reinforcement work.

At the same time, an increase in the bearing capacity of the pile foundation can be achieved by strengthening the soil between the piles and the ground base under the pile. One of the soil strengthening effective methods is the pressure cementation method [3,4]. As a result of the cement mortar pressure injection, compactingthe soil around the pile and under its lower end, which leads to an increase in the soil and pile contact interaction along the lateral surface and the soil resistance increase under the lower end [5-9].

\footnotetext{
*Corresponding author: fsrshakirov@mail.ru
} 
A sources review in this area shows that at present has not been proposed any method for determining the bearing capacity of hanging piles in a cemented soil massif. The available studies give a general picture of the hardened soil characteristics, while there is no data about the effect from the soil strengthening process by cementation on the bearing capacity of the existing pile foundations [3,7, 10-12]. This work purpose is to study the changes in the stress-strain state of the soil around the piles and to quantify the bored pile bearing capacity after strengthening the soil by pressure cementation.

\section{Materials and methods}

To determine changing regularities ofthe bored pile bearing capacity during strengthening the soil by pressure cementation and to quantitatively evaluation the cementationparameters effect on the bearing capacity, were carried out experimental researches in the volumetric tray in the laboratory «Ground bases, Foundations, Dynamics of Structures and Engineering Geology» department of Kazan State University of Architecture and Engineering. For research, was made a scale model of a bored pile from fine-grained concrete in a 1:20 ratio. The pile model has a $3.0 \mathrm{~cm}$ diameter and a $50 \mathrm{~cm}$ total length. The soil for testing was created from fine-grained sand by layer-by-layer filling with uniform compaction. A general view ofthe test tray is shown in Fig. one.

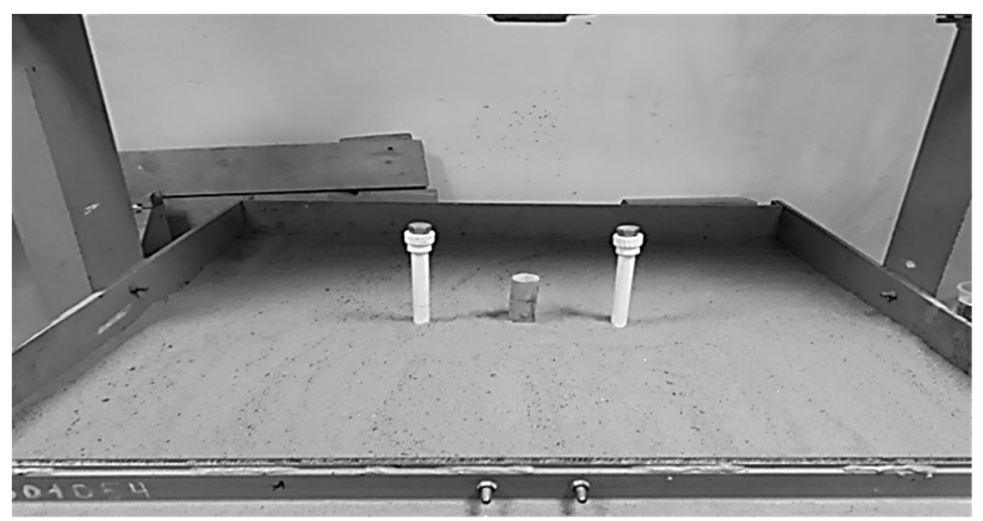

Fig. 1. General view of the test tray (single pile experiment).

Physical and mechanical characteristics of the initial soil are presented in Table. 1.

Table 1. Physical and mechanical characteristics of the soil before testing.

\begin{tabular}{|l|c|c|c|}
\hline \multicolumn{1}{|c|}{ Indicators name } & Symbol & $\begin{array}{c}\text { Measurement } \\
\text { unit }\end{array}$ & Value \\
\hline Specific gravity & $\gamma$ & $\mathrm{kN} / \mathrm{m}^{3}$ & 14.8 \\
\hline Soil particlesspecific gravity & $\gamma_{s}$ & $\mathrm{kN} / \mathrm{m}^{3}$ & 26.5 \\
\hline Drysoilspecific gravity & $\gamma_{d}$ & $\mathrm{kN} / \mathrm{m}^{3}$ & 14.36 \\
\hline Porosity coefficient & $e$ & $\mathrm{s.u}$ & 0.845 \\
\hline Humidity & $W$ & $\%$ & 3 \\
\hline Internal friction angle & $\varphi$ & degree & 25 \\
\hline Soil particlescohesion & $\mathrm{c}$ & $\mathrm{kPa}$ & 2 \\
\hline
\end{tabular}

The pile model and injectors installation for cement mortar injecting into the soil massif was carried out in the process of dumping the soil into the tray. The single pile model, injectors and measuring devicesin the tray location scheme are shown in Fig. 2. 


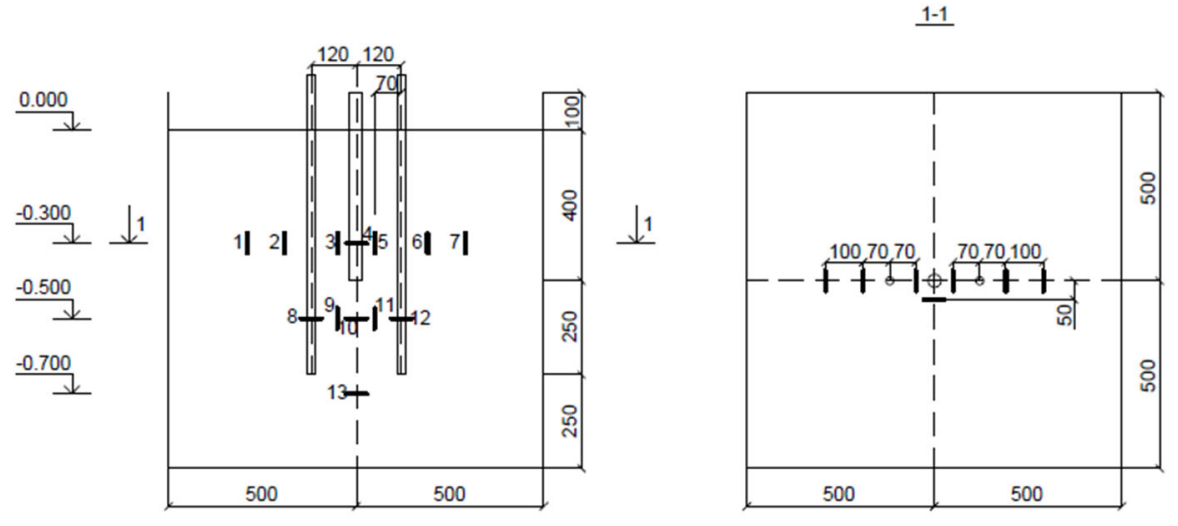

Fig. 2. Pile model, injectors and soil sensors in the tray location scheme(single pile experiment).

In the volume tray were carried out several experiment series with single pile and with a pile cluster, consisting from four piles. At the beginning, before carrying out the experiments with soil cementation, were carried out tests of the pile and pile cluster to determine their bearing capacity in the initial soil. Based on these tests results, was determined the pile total bearing capacity, as well as the bearing capacity along the lateral surface (in the absence of soil resistance under the pile lower end).

Cement mortar was injected into the ground using a KSG-700 mortar pump under a pressure of up to $0.5 \mathrm{MPa}$ through plastic injectors. The injectors in the injection zone have perforations on four sides - holes with a $3 \mathrm{~mm}$ diameter. As a strengthening solution was used water-cement suspension with a water-cement 0.7 ratio, prepared from Portland cement grade 400. After the solution was injected into the soil mass and hardened for 5 days, were taken data from the pressure sensors installed in the soil mass. Subsequently, the piles were tested with a vertical static indentation load.

\section{Results}

As showsthe obtained experimental results, at the cement mortar injection into the sandy soil, the soil compaction around the injector occurs relatively uniformly in the radial direction, as a result, after the mortar hardens, is formed a soil-cement element, which is close to cylindrical in shape, but variable in cross-section height. Around this soil-cement column forming a compacted soil zone, the dimensions of which, depends on the injected mortarvolume. When the injection pressure reaches a certain critical value, it causes thesoil hydraulic fracturing, and the mortar begins to spread to the sides along the formed paths (cracks) in the soil. To retain and accumulate the largest volume of cement mortar in the injection zone, as it is supply into the soil mass, it is necessary to smoothly increase the pressure to the required value without sudden jumps [13-17].

If the injector located next to the reinforced pile or in the between pile space of the pile cluster, as a cement mortar injection result, the soil density increases and increases the soil pressure on the pile lateral surface. The compaction degree to certain limits depends on the volume of the injected mortar, in each case there is a limiting mortar volume value at which the density of the soil reaches its maximum value and does not increase further [18-20]. Compaction of the soil is reached due to a more compact soil particles arrangement and a decrease in their porosity $[10,21-26]$. Compaction is also reachedby a temporary sand humidity increase during cementation due to the water release into the soil by the cement mortar. During the experiments, the sand humidity increase in the injection zone was from 
$3 \%$ to $7-10 \%$. It was found that the increase in soil density occurs to a greater extent at the pile lateral surface, and less under the pile lower end. The sand density changinggraph depending on the volume of the injected mortar is shown in Fig. 3.

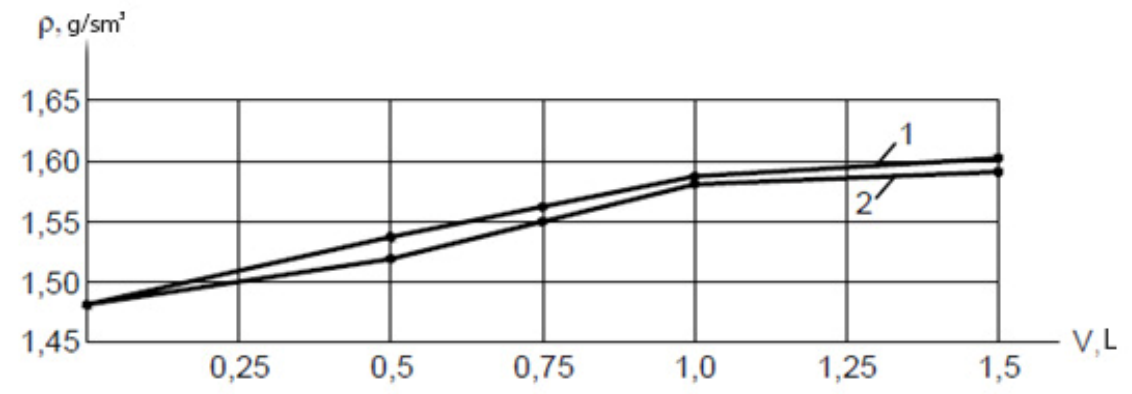

Fig. 3. Soil density changing graph in depending on the volume of the injected mortar $(1-$ at the side surface, 2 - under the lower end).

During the cement mortar injection, the horizontal compressive stresses in the soil section between the pile and the injector increase sharply, reaching about 20-30 kPa. After removing the injection pressure in the soil, stress relaxation occurs, therefore, after a short time, the stresses in the same zone were no more than $10 \mathrm{kPa}$. In Figures 4 and 5 shown the graphs of horizontal stress changes in thepile lateral surface area at a depth of $30 \mathrm{~cm}$, measured according to the soil sensors data after stabilization of stresses at the cementmortar injection end and at testing the pile model with a static load. As can be seen from the graphs, at the cementmortar injection, the stresses in the soil around the pile increase, under static loading it initially continues to grow, and after the pile «breaks», it sharply decreases.

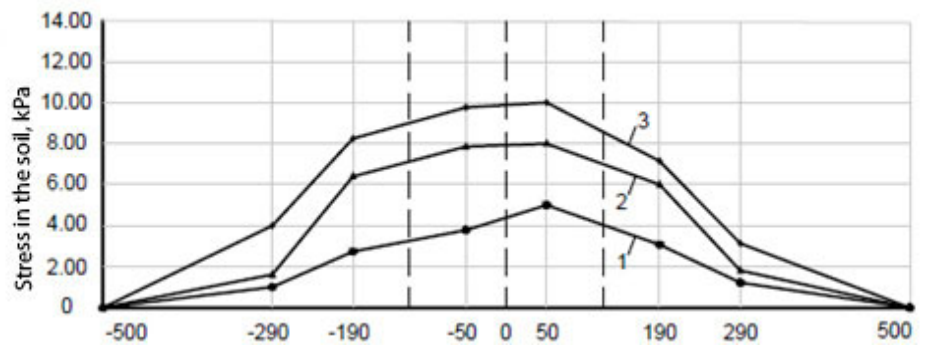

Fig. 4. Horizontal stresses changing at a depth of $30 \mathrm{~cm}$ after cement mortar injection (1, 2, 3 - when the volume of the injected cement mortar per injector is $0.5,1.0$ and 1.5 liters, respectively).

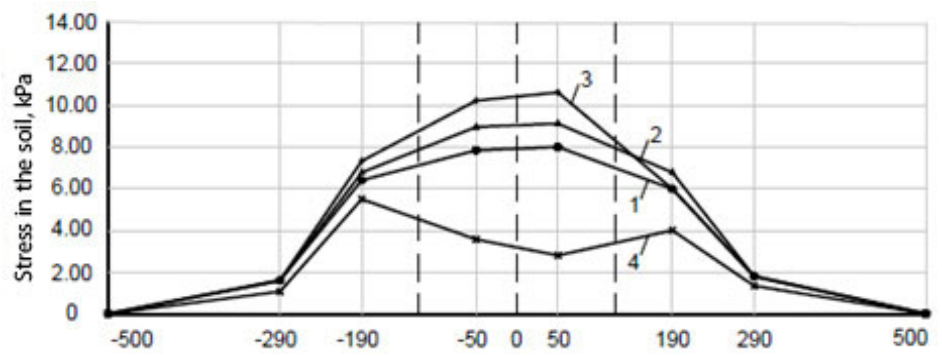

Fig. 5. Horizontal stresses changing at a depth of $30 \mathrm{~cm}$ when the pile is loaded with a static load (1 after the cement mortar injection; 2, 3, 4 - when the load on the pile is 8,16 and $24 \mathrm{kgf}$, respectively; experiment No. 5). 
The dependence graphs of the pile settlement from the applied load at various reinforcing mortar injection parameters are shown in Fig. 6.

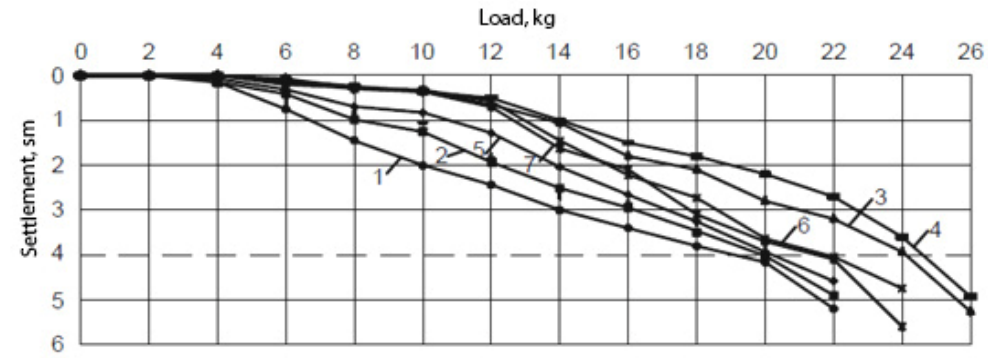

Fig. 6. Dependence graph of the pile settlement from the applied load on the pile ( 1 - before soil strengthening; 2, 3, 4- reinforcement in the lateral surface area; 5, 6, 7 -reinforcement under the lower end, with the volume of the injected cement mortar on the injector, respectively $0.5,1.0,1.5 \mathrm{l}$ )

During the experiments, an increase inthe soil internal friction angle atthe ground massif in compacted zone during the cement mortar injection was found from 250 to 310 , the highest value of this indicator was fixed between the injector and the pile.

The results obtained during the research are given in Table 2.

Table 2. Cementation technological parameters and experimental results.

\begin{tabular}{|c|c|c|c|c|c|c|c|c|}
\hline \multirow{2}{*}{$\begin{array}{l}\text { Experiment } \\
\text { number }\end{array}$} & \multirow[b]{2}{*}{$\begin{array}{c}\text { Number } \\
\text { of piles }\end{array}$} & \multirow[b]{2}{*}{$\begin{array}{l}\text { Number } \\
\text { ofinjectors }\end{array}$} & \multirow{2}{*}{$\begin{array}{c}\text { Cement } \\
\text { mortar } \\
\text { volume per } \\
\text { injector, } 1\end{array}$} & \multirow[b]{2}{*}{$\begin{array}{l}\text { Injection } \\
\text { zone }\end{array}$} & \multicolumn{3}{|c|}{$\begin{array}{l}\text { Bearing capacity of } \\
\text { the pile model, } \mathrm{kgf}\end{array}$} & \multirow{2}{*}{$\begin{array}{l}\text { Soil } \\
\text { density } \\
\text { at the } \\
\text { pile, g / } \\
\mathrm{cm}^{3}\end{array}$} \\
\hline & & & & & total & side & bottom & \\
\hline 1 & 1 & - & - & - & 19.1 & 6.6 & 12.5 & 1.48 \\
\hline 2 & 4 & - & - & - & 22.0 & & & 1.48 \\
\hline 3 & 1 & 2 & 0.5 & $\begin{array}{c}\text { side } \\
\text { surface }\end{array}$ & 19.9 & 7.4 & & 1.53 \\
\hline 4 & 1 & 2 & 0.75 & $\begin{array}{c}\text { side } \\
\text { surface }\end{array}$ & 21.4 & 8.9 & & 1.561 \\
\hline 5 & 1 & 2 & 1.0 & $\begin{array}{c}\text { side } \\
\text { surface }\end{array}$ & 24.1 & 11.6 & & 1.575 \\
\hline 6 & 1 & 2 & 1.5 & $\begin{array}{c}\text { side } \\
\text { surface }\end{array}$ & 24.6 & 12.1 & & 1.605 \\
\hline 7 & 1 & 2 & 0.5 & bottom & 20.2 & & 13.6 & 1.52 \\
\hline 8 & 1 & 2 & 0.75 & bottom & 20.9 & & 14.3 & 1.546 \\
\hline 9 & 1 & 2 & 1.0 & bottom & 21.5 & & 14.9 & 1.577 \\
\hline 10 & 1 & 2 & 1.5 & bottom & 21.8 & & 15.2 & 1.59 \\
\hline 11 & 4 & 1 & 1.0 & $\begin{array}{c}\text { side } \\
\text { surface }\end{array}$ & 23.8 & & & 1.586 \\
\hline 12 & 4 & 1 & 1.0 & bottom & 25.1 & & & 1.564 \\
\hline 13 & 4 & 4 & 1.0 & $\begin{array}{c}\text { side } \\
\text { surface }\end{array}$ & 24.2 & & & 1.610 \\
\hline 14 & 4 & 4 & 1.0 & bottom & 27.0 & & & 1.607 \\
\hline
\end{tabular}




\section{Discussion}

As a result of cement mortar injection, there was an increase in the contact interaction between the soil and the pile. In addition, during the solution hardening in the soil, were formed rigid inclusions, reinforcing the soil mass and enhancing the effect of soil compaction and interaction with the pile.Based on the carried out experiments results analysis, to determine the piles bearing capacity after strengthening the soil by pressure cementation, the formula SP 24.13330.2011 offers to use with the correction factors addition to the design resistances $\operatorname{Rand} f_{i}$ tabular values:

$$
F_{d}=\gamma_{c}\left(\gamma_{c R} \cdot \xi_{R} \cdot R \cdot A+u \cdot \sum_{i=0}^{n} \gamma_{c f i} \cdot \xi_{f i} \cdot f_{i} \cdot h_{i}\right)
$$

where, the coefficients $\xi_{R}$ and $\xi_{f i}$ take into account the soil compaction degree during the cement mortar injection. These coefficients depend on thecement mortarinjected volume, the initial soil density and the injectorsinstallation scheme relative to the pile. According to the obtained experimental data, in the case of sandy soils, the $\xi_{R}$ coefficient varies within $1.05 \ldots 1.2$, the $\xi_{f i}$ coefficient - within $1.1 \ldots 1.6$. It should also be noted that when the pile foundation is strengthened by cementation, soil-cement elements are formed that resemble a bored injection pile in shape. At calculatinga pile cluster total bearing capacity after strengthening the foundation with pressure cementation, the bearing capacity of these elements can be taken into account $[11,12,27]$. The soil-cement elements cross-section area and perimeter are proposed to be determined based on the element average diameter:

$$
d_{u}=\sqrt{\frac{4 \cdot V \cdot \kappa_{n} \cdot \kappa_{z}}{l \cdot \pi}}
$$

where, $\mathrm{V}$ is the injected cement mortarvolume;

$l-$ is the injector perforated part length;

$\kappa_{n}$ - coefficient taking into account the cement mortarlosses during injection;

$\kappa_{z}$ - coefficient taking into account the increase in the cement mortar volume due to mixing sandy soil with cement mortar, depending on the cement mortarconsistency (water-cement ratio) and sandy soil characteristics.

\section{Conclusions}

According to the performed experiments, regular variations in the stress-strain state of the soil massif around the bored pile were determined, depending on the cement mortar injected volume. The soils pressure cementation surrounding the pile leads to pile compression and an increase in friction along the pile lateral surface, and to a lesser extent to an increase in the pile frontal resistance - during the soilstrengthening under the pile lower end. In the accepted soil conditions, the increase in the soil density near a single pile after the cement mortar injection was up to $8.8 \%$, the increase in the piles bearing capacity along the lateral surface up to $80 \%$, under the lower end up to $20 \%$. In the case of the pile cluster soil strengthening in the between-pile space, bearing capacity increase of each individual pile in the cluster is greater than in a single pile, with the same reinforcing mortar injection technological parameters. Based on this, we can conclude that the pressure cementation greatest effect is achieved when soil is strengthened under pile foundations with a cluster arrangement of piles and under raft-pile foundations.

\section{References}


1. I. T. Mirsayapov, I. V.Koroleva, Long-term Settlements Assessment of High-rise Building Groundbase Based on Analytical Ground Deformation Diagram, Procedia Engineering 165, 519-527 (2016), DOI: 10.1016/j.proeng.2016.11.728

2. L. F.Siraziev, Experimental studies of the stress-strain state of layered soil bases under the center of the stamp during short-term tests, Innovations and Investments 11, 225228 (2018), DOI: 10.1016/j.proeng.2018.04.007

3. I. T. Mirsayapov, I. V.Koroleva, The strength and deformability of clay soils under the regime spatial stress state in view of cracking, Grounds, foundations and soil mechanics 1, 16-23 (2016), DOI: 10.1061/(ASCE)GM.1943-5622.0001580

4. I. T.Mirsayapov, I. V.Koroleva, Changes in physical and mechanical characteristics of soil under triaxial loading. In: CRC Press. CONFERENCE, 466, 193-196 (2019), DOI: 10.1201/9780429058882-37

5. I. T.Mirsayapov, N. N.Aysin, Influence of a deep construction pit on a technical condition of surrounding buildings, In: CRC Press. CONFERENCE, 466, 197-201 (2019), DOI: 10.1201/9780429058882-38

6. I. T.Mirsayapov, I. V. Koroleva, Calculation models of bearing capacity and deformation of soil foundations with vertical elements reinforced under regime cyclic loading, Springer Series in Geomechanics and Geoengineering, 502-507 (2019), DOI: 10.1007/978-3-319-99670-7_62

7. I. Mirsayapov, D. Sabirzyanov, Bearing capacity of foundations base under combined alternating long-term static and cyclic loadin, In: CRC Press. CONFERENCE 2018, 700, 43-51 (2018), DOI: 10.1088/1757-899X/890/1/012069.

8. I. T.Mirsayapov, I.V.Koroleva, Settlements assessment of high-rise building groundbase using transformed ground deformation diagram, In: IACMAG. CONFERENCE 2017, IACMAG, 914, 784-792 (2017), DOI:10.1007/s40091-0190213-9

9. I.T.Mirsayapov, I. V. Koroleva, Calculation models of bearing capacity and deformation of soil foundations with vertical elements reinforced under cyclic loading, In: ICSMGE. CONFERENCE 2017, ICSMGE, 3254, 2599-2602 (2017), DOI: 10.1007/978-3-319-99670-7_62

10. I. T. Mirsayapov, M. I. Shakirov, Combined plate-pile foundations settlement calculation under cyclic loading, Socio-Technical Construction and Civil Engineering: IOP Conf. Series: Materials Science and Engineering, 1-8 (2020) DOI:10.1088/1757899X/890/1/012069

11. I. F. Shakirov, D. R. Garifullin, The research of bearing capacity and deformation of sandy ground, reinforced by pressure cementation, Izvestiya KGASU, 4(34), 200-205 (2015)

12. N. Z. Gotman, A. L. Gotman, Determination of the deformation modulus strengthened by ground cementing, Izvestiya KGASU, 1(39), 138-144 (2017)

13. I. T.Mirsayapov, I. V. Koroleva, Strength and Deformability of Clay Soil Under Different Triaxial Load Regimes that Consider Crack, Soil Mechanics and Foundation Engineering, 53, 5-11 (2016) DOI: 10.1007/s11204-016-9356-x

14. I. Mirsayapov, I. Koroleva, Long-term Settlements Assessment of High-rise Building Groundbase Based on Analytical Ground Deformation Diagram, Procedia Engineering 165, 519-527 (2016), DOI: 10.1016/j.proeng.2016.11.728

15. I. T.Mirsayapov, I. V. Koroleva, D. D.Sabirzyanov, Calculation model of foundation base settlement at the static and cyclic regime loading, In: ICEGT. CONFERENCE 2016, ICEGT, 756, 429-434 (2016) DOI: 10.1201/b21938-68

16. I. T. Mirsayapov, I. V. Koroleva, Computational Model of the Carrying Capacity of a Reinforced Foundation with Cyclic Loading, Soil Mechanics and Foundation Engineering, 52, 198-205 (2015) DOI: 10.1007/s11204-015-9328-6. 
17. I. T. Mirsayapov, I. V. Koroleva, Sediments foundation bases under long-term regime loading, in ARC. Conference 2015, ARC, 1596, 1398-1401 (2015) DOI: 10.3208/jgssp.KAZ-17

18. I. T. Mirsayapov, I. V. Koroleva, Bearing capacity of foundations under regime cyclic loading, in ARC. Conference 2015, ARC 1596, 1214-1217 (2015) DOI: 10.3208/jgssp.KAZ-18

19. I. T. Mirsayapov, I. V. Koroleva, Clayey soils rheological model under triaxial regime loading, in ECSMGE, Conference 2015, ECSMGE 3976, 3249-3254 (2015) DOI: 10.1016/j.proeng.2015.11.728

20. I. T. Mirsayapov, I. V. Koroleva, Experimentaland theoretical studies of bearing capacity and deformation of reinforced soil foundations under cyclic loading, In: IACMAG. Conference 2014, IACMAG, 1525, 737-742 (2015) DOI: 10.1201/b17435127

21. I. T. Mirsayapov, M. I. Shakirov, Bearing capacity and settlement of raft-pile foundations under cyclic loading, in ICEGT. CONFERENCE 2016, ICEGT, 756, 423428 (2016) DOI: 10.1201/b21938-67

22. I. T. Mirsayapov, I. V. Koroleva, I. I. Mirsayapova, Evaluation of seismic stability of layered soil bases in areas that are composed of clays and water-saturated sandstones, in ARC. Conference 2015, ARC, 1596, 719-722 (2015) DOI: 10.3208/jgssp.OTH-29

23. I. T. Mirsayapov, I. V. Koroleva, Bearing capacity and deformation of the base of deep foundations' ground base, in ISSMGE. CONFERENCE 2014, ISSMGE 1962, 401-404 (2014) DOI: 10.1201/b17240-74

24. I. T. Mirsayapov, I. V. Koroleva, Prediction of deformations of foundation beds with a consideration of long-term nonlinear soil deformation, Soil Mechanics and Foundation Engineering, 48, 148-157 (2011) DOI: 10.1007/s11204-011-9142-8

25. I. T. Mirsayapov, A study of stress concentration zones under cyclic loading by thermal imaging method, Strength of Materials, 41, 339-344 (2009) DOI: 10.1007/s11223-0099121-8

26. R Khuziakhmetov, D. Nurieva, Determination of the Reasons for the Fallof Pile Driving Machine Main Technical Near the Slope of the Foundation Pit IOP Conference Materials. Science Engeering, 890, 162-170 (2020) DOI: 10.1088/1757899X/890/1/012136

27. I. F. Shakirov, S. I. Tyurkin, Researches of bearing capacity of hanging piles in the array of soil, reinforced by pressure cementation, Perspective directions of development in theory and practice of rheology and soil mechanics, XIV International Symposium on the rheology of soils, KGASU, Kazan, 75-80 (2014) 